\section{RESEARCH GRANTS}

Dr M de Swiet and Mr E Shinebourne, Cardiothoracic Institute, London: $\$ 47120$ by the British
Heart Foundation for a study of blood pressure in

Heart Foun
children.

Dr Hugh Sinclair, International Institute of Human Nutrition, Abingdon: $\mathbf{6 4 4 5 7 0}$ by the British Hear Foundation for research into the causes of the accumula tion of fats in the walls of diseased blood vessels. With E17 543 for research into the contribution of trace 117 543 for research into the contribution of trace
metals in the diet to the arterial degeneration that
affects many diabetics.

Dr B Bellhouse and Dr N Harding, department of engineering science, Oxford University: $\mathbf{1 4 7 3 6}$ by blood to the synthetic compounds used in equipment required for modern heart surgery.

Dr S Cederholm-Williams, John Radcliffe Hospital: $\mathbf{2 1} 543$ by the British Heart Foundation for research into cell cultures as a source of plasminogen. Dr D Noble, physiology laboratory, Oxford University:

Dr Jan Lawrie, University of Edinburgh: $£ 22179$ by the British Heart Foundation for studies of the thrombosis.

Dr D Ellis, University of Edinburgh: $£ 7798$ by the British Heart Foundation for research into the effects of of heart muscle.

\section{COMING EVENTS}

British Medical Association East Anglian OfficeDetails of training sessions organised in conjunction with the DHSS on the Social Security and Housing
Benefits Act, 21 March, Norwich, and 29 March, Cambridge, are available from the office, 10 Downing

British Medical Association-Meeting for the north west region on BMA Services Limited, 28 March, Mr David Melvin, BMA, Boyd House, Upper Park British Medical Association-Contract clinics for final year associate member, 28 March, Leicester, and
Harch, Birmingham. Details from the BMA, 36
Harborne Road, Birmingham B15 3AJ.

Association of Medical Advisers in the Pharmaceutical Industry-Symposium "Histamine: physio-
logical, clinical, and commercial aspects," 29 March,
London. Details from Mrs J Wase-Bailey of the as sociation, 41 Queen's Gate, London SW7 5HU. (Tel

Bureau for Overseas Medical Service-Details of an open meeting for doctors and paramedical staf London, are available from the bureau, London School of Hygiene and Tropical Medicine, Keppel Street
(Gower Street), London WC1E 7HT. (Tel 01-636 8636.) Royal Society-Meeting for discussion "Mathematical genetics (incorporating the 11th R A Fisher memoria lecture)," 20 April, London. Details from the executive London SW1Y 5AG, reference DM7/CAJ. (Tel 01-839 5561 ext 278 or 277 .)

"Data protection and information privacy"Conference organised by the University of Leicester from Mrs K B Penny of the department of adult education in the university, Leicester LE1 7RH. (Tel 0533 554455 ext 242.)

Royal Medical Benevolent Fund-Details of the 146th annual general meeting, 12 May, Royal College the fund, 24 King's Road, Wimbledon, London SW 19 $8 Q N$.

Order of Christian Unity-Conference "In vitro fertilisation and the quality of life," 23 May, London Unity House, 58 Hannover Gardens, London SE1 $5 \mathrm{TN}$

International Union Against Cancer-Workshop on doctor involvement in public education about cancer, union, 3 rue du Conseil-Général, CH-1205 Geneva, Switzerland.

International Conference on Offshore Safety and Health-18-20 October, Halifax, Nova Scotia. Details from ICOSH, PO Box 3200,
Nova Scotia, Canada B3J 3H5.

Welsh National School of Medicine Dermatology Department-Details of the "5th investigative techniques in dermatology course," 16-18 November, and an international symposium on "Skin modelssponsored by the European Society for Dermatological Research, 15-17 March 1984, Cardiff, are availabl Welsh National School of Medicine, Heath Park,

Glasgow Orthopaedic Training Committee-
Mr James $R$ Loudon, chairman of the committee,
Victoria Infirmary, Orthopaedic and Accident Unit, Glasgow G42 9TY.

St George's Hospital Medical School-Details and meetings organised by the obstetrics and gynaecology department are available from the department, Cranmer lectures will be published in our Societies and Lectures column.

\section{SOCIETIES AND LECTURES}

For attending lectures marked ${ }^{*}$ a fee is charged or a ticket is required. Application
institutions concerned.

\section{Monday, 21 March}

St George's Hospital Medical School-12 30 pm, obstetrics and gynaecology departmental postgraduate hypnosis.

\section{Tuesday, 22 March}

Birmingham Medical Institute Midland Medical SOCIETY SECTION-8 $15 \mathrm{pm}$, Dr Malcolm Nattrass Recognised under Section 63.) WELLCOME INSTITUTE FOR THE HISTORY OF MEDICINE$6 \mathrm{pm}$, Professor A McG Harvey: The university
clinic: its evolution in Great Britain and the United States.

\section{Wednesday, 23 March}

Institute of DeRmatology-4 45 pm, Dr R A Marsden: Bullous disease in infancy.
NATIONAL HeART HOSPITAL-At Institute of Child NATIONAL HEART HOSPITAL-At Institute of Child
Health, $530 \mathrm{pm}$, surgical lecture 1983 by Dr Aldo Castaneda: The neonate and infant with critical congenital heart disease : a surgeon's view. RoYAL COLLEGE OF SURGEONS OF ENGLAND-5 pm, changing face of parathyroid surgery.
ROYAL FREE HOSPITAL SCHOOL OF MEDICINE- $5 \mathrm{pm}$, Professor Lesley Rees: Endorphins and enkephalins. Royal MASONIC HoSPITAL-7 pm, Dr D N Croft: The clinical presentation and recognition of thyroid disease. (Preceded by refreshments $630 \mathrm{pm}$.) ture Theatre, $1015 \mathrm{am}$, medical staff round.

Thursday, 24 March

QueEn Charlotte's Maternity Hospital-12 15 pm Dr Jackie James: Ionised calcium in neonates.

OYAL COLLEGE OF SURGEONS OF ENGLAND-At Roya College of Obstetricians and Gynaecologists, $5 \mathrm{pm}$,
Victor Bonney prize lecture by Mr J A Jordan: The Victor Bonney prize lecture by $\mathrm{Mr} \mathrm{J} \mathrm{A} \mathrm{Jord}$
impact of laser microsurgery on gynaecology.

\section{Friday, 25 March}

Royal College of Surgeons of ENGLAND- $5 \mathrm{pm}$ Hunterian lecture by Professor D K C Cooper: Orthoptic and heterotopic transplantation of the
heart: the Cape Town experience. At St James's University Hospital, Leeds, $5 \mathrm{pm}$, Hunterian lecture by Professor $R$ Kesster: The thrombogenicity of Dacron arterial grafts and its modification by platelet-
inhibitory drugs. inhibitory drugs.

ROYAL FREE HOSPITAL SCHOOL OF MEDICINE-12 $30 \mathrm{pm}$ the enemy.

\section{BMA NOTICES}

\section{Rheumatology and rehabilitation subcommittee (CCHMS)}

A ballot is shortly to be held among senio hospital medical staff in rheumatology and rehabilitation in the NHS for representatives to serve on the rheumatology and rehabilitation subcommittee of the Central Committee for Hospital Medical Services on the basis of nominations received before 11 March 1983

The attention of the electorate is drawn to the fact that staff holding honorary consultant appointments are not eligible to vote unless their contract is of the A and B type-that is, including a paid NHS appointment.

Any eligible staff who do not receive a ballot paper may obtain one from the secretary of the BMA.

J D J HAVARD
Central meetings

MARCH

27 Sat and Junior Members Forum (University of APRIL

$6 \mathrm{Wed}$ Finance and general purposes committee, $6 \mathrm{Wed} \quad 10$ am. 12 Tues Joint Consultants Committee, $930 \mathrm{am}$

\section{Division meetings}

Members proposing to attend meetings marked * are asked
to notify in advance the honorary secretary concerned.

Bath District-At Royal United Hospital, Friday, 25 March, divisional dinner, guest Mr Ronald Hicks.

Burton on Trent and District-At Stanhope
Arms Hotel, Tuesday, 22 March, 730 for 8 pm, ladies Arms Hotel, Tuesday, 22 March, 730 for 8 pm, ladies" and nonsense."* (Wives and other guests invited.) Ealing-At Ealing Hospital, Tuesday, 22 March, $715 \mathrm{pm}$, joint meeting with the Pharmaceutical Society Ealing Branch, speaker Dame Cicely Saunders: "The nature and managen
supper provided.)

East Surrey-At Redhill Postgraduate Medical Centre, Tuesday, 22 March, $730 \mathrm{pm}$, chairman's
evening, Mr Charles Cory: "Shingles in ophthalmology." "* (Buffet supper provided.)

Fife-At Dunnikier House Hotel, Thursday, 24 Masch, 7 for $730 \mathrm{pm}$, joint meeting with East Fife "Antiviral agents." ( (Refreshments served.) $22 \mathrm{March}$, $730 \mathrm{pm}$, joint meeting with the West Surrey Law Society Group on "Alcoholism."* (With buffet supper.) Kingston, Richmond, and Epsom-At RAC
Country Club, Wednesday, 23 March, 730 for $8 \mathrm{pm}$, ing some of his experiences in the Falklands Island campaign.* (Guests invited)

North Birmingham, Lichfield, and TamorthAt George Hotel, Lichfield, Thursday, 24 March 730 for $8 \mathrm{pm}$, antique evening with $\mathrm{Mr} M$ Smedley. Hot fork buffet.* Spouses and guests welcome.

Peterborough-At Peterborough District Hospital,

Tuesday, 22 March, $730 \mathrm{pm}$, agm.
Redbridge and Stratford-At King George Hospital, Ilford, Tuesday, 22 March, 8 pm, Professo (Preceded by buffet supper 730 pm. Guests most welcome.)

Southend on Sea-At Postgraduate Centre, March, $730 \mathrm{pm}$, illustrated introduction windsurfing.* (Supper provided.)

South Warwickshire-At Regent Hotel, Leaming ton Spa, Wednesday, 23 March, $730 \mathrm{pm}$, joint dinne meeting with Warwickshire BDA, speaker Surgeon periences in the Falklands." * (Wives and families

Swansea and West Glamorgan-At Dragon talk by Mursday, 24 March, 730 for $8 \mathrm{pm}$, dinner and of students A W Maclean: "Selection and admission West to medical school."* (Guests invited.) Wednesday, 23 Mre-At Royal Berkshire Hospital, John Walton: "Clinical medicine: its challenges and it responsibilities." (Preceded by buffet supper 730 pm.

\section{Regional meeting}

Northern Regional Council-At Royal Station dinner dance.* (Guests wyne, Friday, 25 March,

\section{Correction}

\section{Voting and the mentally ill}

We regret that in the final section of the medicolega article on "Voting and the mentally ill" (12 March, p 899) the second sentence of the first paragraph was omitted. This section should have read: "The declaration may be made only, however, if the individual can do so without assistance. Paragraph 3(9) provides that assistance does not include assistance necessitated by blindness or other physical incapacity."

\section{(i) British Medical Journal 1983}

All Rights Reserved. No part of this publication may be reproduced, stored in a retrieval system, or transmitted, in any form or by any means, electronic, mechanical, 